\title{
Project Management Toxic Leadership: Implications for Managing a Road-Tunnel Project in Bangladesh
}

\author{
Dr Paul James \\ Graduate School, Bangkok University \\ Rama 4 Road, Klong-Toey, Bangkok, Thailand \\ E-mail: paul.j@bu.ac.th
}

Received: Jan. 29, 2018

Accepted: March 22, 2018

Published: April 1, 2018

doi:10.5296/jmr.v10i2.12779

URL: https://doi.org/10.5296/jmr.v10i2.12779

\begin{abstract}
This is a research paper that is focused on assessing the leadership impacts of Project Management (JV Lead Management) on a road tunnelling construction project in Bangladesh in terms of project performance. An interpretive methodology was utilised in order to help understand implicitly the management leadership's impact on the project. The scope for this research was the off-site supervisory team. The targeted population of interest was made up of 14 lower-managers/engineers located at one off-site main office in the late design stage/early construction phase of a road-tunnelling project.

The research outcomes consisted of four4 main themes and the corresponding 11 sub-themes.

The paper addresses raised issues and determines outcomes and implications for the continuing project construction management and the paper also indicates that the Project Management and other senior members of the JV Lead Management - both in-country and overseas -may benefit from more effective leadership training focused on utilizing and embracing contemporary project leadership developments.

The road tunnel construction management appears to be very weak due to their low level of technical knowledge, style, orientation and strategies adopted by the Project Management, who operate with a demonstrated lack of coherent leadership or oversight practiced by the JV Lead managing entity.
\end{abstract}

Keywords: Toxic Leadership, JV, Construction Project, Corruption, Bangladesh 


\section{Introduction}

One of the major roles of project management in complex projects is to lead others (Remington and Pollack, 2007), improve methods, processes and communication and consistently enhance project performance (Turner and Müller, 2005) in order to make the project a success for the client and other stakeholders (Lim and Mohamed, 1999; Baccarini, 1999). Failures are often due to a mismatch between the project management capability and motivation, technical project understanding (Tan, 2004; Hillson, 2003) and with the project's managerial requirements (Crawford, 2000; Wysocki and Lewis, 2001). This is also compounded when the project management acts directly as an agent of the Client (Cerić, 2015), rather than as an independent or consultant engineer (FIDIC, 1999) for both the Contractor and the Client, thus, illustrating hidden intentions (Jäger, 2008).Leading a complex project therefore has implications for managing people and resources (Cavaleri and Reed, 2008). However, much leadership research attention has addressed an understanding of effective leaders (Yukl, 1999; James, 2005); but very little conducted on such leadership traits and behaviours associated with ineffective leaders (Kellerman, 2004), destructive leaders (Harris, Kacmar and Zivnusk, 2007) or toxic leaders (Rumsey, 2013). Further, within construction projects only an emerging state of research has been conducted on the impacts of toxic leadership practices (Toor and Ogunlana, 2009) and little or no research relating toxic leadership to possible corruption practices. Thus, this research is centred on illuminating aspects of "dark leadership" (Conger, 1990; Harms, Spain and Hannah, 2011) that may help with developing a more involved leadership theory.

\section{Toxic Leadership}

Toxic leaders are those individuals who engage in destructive behaviour towards their employees (Sankowski, 1995) without thinking of the consequences of their actions (Goldman, 2009). This leads to visible, egocentric and narcissistic behaviour (Conger, 1989; Yukl, 1999) and dysfunctional corporate relationships in which the leader is seen as incapable and underperforming (Lipman-Blumen, 2005), whilst inflicting serious harm on others that goes unacknowledged or ignored by senior management(Ashforth, 1994; Conger, 1990).

The literature indicates clearly that where toxic leadership is recognised, the organisation is being run to "destruction" (Reed, 2004) where it could be further seen as a defence mechanism to protect the illegal corruption activities being conducted by managements overseeing the project (Pelletier and Bligh, 2008)through collusion (Locatelli, et al., 2017).

Müller and Turner (2007) indicate that toxic leadership is a structural response to the mismatch between project type and JV Lead Management leadership style (Powl and Skitmore, 2005) and are seen by many researchers as being ineffective (Kellerman, 2004), when viewed with personal traits and organisational factors (Harvey et al., 2007) and appear destructive in terms of performance and personal responses (Harris, Kacmar and Zivnuska, 2007). However, leadership is required to help pursue major stakeholder satisfaction resulting in a project's success (Toor and Ogunlana, 2008).If a project's leadership behaviour changes to a destructive mode, then the major stakeholder's also show such destructive leadership tendencies (Toor and Ofori, 2008; Shaw, Erickson and Harvey, 2011) creating vulnerable work environments 
(Padilla, Hogan and Kaiser, 2007) raised from such narcissistic and manipulative leadership behaviour (Rosenthal and Pittinsky, 2006). For example, in susceptible work environments, toxic leaders often utilise control, bullying and coercion (Hogan, Hogan and Kaiser, 2003), and abusiveness (Tavanti, 2011) as their main method for ensuring authoritive acceptance (Higgs, 2009)through narcissism (Maccoby, 1999) related to unethical behaviour (Niehus, 2011) and lack of integrity (Blair, Hoffman and Helland, 2008). Significantly, outcomes of toxic leadership often indicate employee disconnect and exit the company (Branham, 2005) increasing costs (Reed, 2004), reducing professional inputs and negatively affecting project performance (Buckingham and Coffman, 1999; Wilson-Starks, 2003). Further, toxic leadership in construction projects appears to introduce a deliberate element of negative focus on project performance and activities that are instrumental in crafting destructive project outcomes (Yukl, 1999).

This research is focused on the first major road tunnelling project in Bangladesh, where the oversight of the EPC project by the "Assistant Engineer" is managed by an JV Lead Partner an internationally experienced managing entity (for JV Lead Management). No national nor employer managing entity has any experience in tunnelling management or experience in tunnelling under rivers. The context for the research is a new road tunnelling project with an initial start cost of US $\$ 1.07 \mathrm{Bn}$ that has been delayed for 2.5 years.

This creates the context for the research question,In what ways do Toxic Leadership affect the management, personnel and performance of a Road-Tunnel Project in Bangladesh?

\section{Methodology}

Exploring toxic leadership in a tunnelling infrastructure project in Bangladesh, demands a qualitative inquiry to stimulate and discriminate more explicitly the issues formed within this context (Hill, Thompson and Williams, 1997; Walsh, White and Young, 2008). This consideration targets national and international engineering personnel judgements raised out of individual experiences. This research endeavours to understand the opinions and attitudes of project personnel, who were considered authoritive "knowledge agents" (Benn et al., 2008), and provide an appropriate contextual component (Cassell and Symon, 2004) as their experiences provided of found engagement in their material perceptions of managerial project practices.

The exploration employed a semi-structured interview process, which was further reinforced through exploiting an inductive/theory building approach (Glaser and Strauss, 1967) through appropriate "documentation" scrutiny. Because of the sensitivity and impact of the elaborate leadership environment on the project, and the lack of published research in this area, this methodology is designed for constructing appropriate contextual data for the purpose of forming rich content and consequent theory development (Cayla and Eckhardt, 2007). A pilot study was carried out with three (3) respondents from the population and excluded from the main interview process (Maxwell, 2013) that endorsed changes to language and the logic of probing questions to respondents (Kim, 2011) and created more informed and streamlined question routine (James and James, 2011). 
Aclosed population of fourteen (14), all contained within an identified research frame (Ritchie and Lewis, 2003; Fink, 2000), was made up of all lower-managers/engineers who had on-going direct project related experiences. Respondents were chosen through employing the approach of a "population of interest" (Carman, 1990) ensuring empirical adequacy (Spanos, 1990).

The interview process was conducted in English and took approximately one hour, and was recorded with permission (Duranti, 2007). Using Gray and Wilcox (1995) and (James, 2014), each individual was questioned using an identical set of questions -whilst utilising probing questions (Balshem, 1991; Punch, 2014; Meurer, et al., 2007). Each individual verbatim transcription using NVivo 11 (after Bailey, 2008) was returned to each respondent (Harris and Brown, 2010) for comment, correction, addition or deletion and return where whole-process validity was preserved by conjoining the adopted main research question to the data outcomes (Stenbacka, 2001).

For the data analysis procedure, each interview was initially manually and independently interrogated and a coded treatment surfaced relative to the thematic analysis using NVivo 11 (Walsh, White and Young, 2008). No portion of any interview discourse was left uncoded and the overall outcome represented the respondent's views through a progressive coding-sequence (Buston, 1999).

Themes were developed out of the data interrogation where validity was increased using triangulation processes (Onwuegbuzie and Leech, 2007). Further, sub-theme analysis was conducted using all complete data sets (Harwood and Garry, 2003; Ryan and Bernard, 2003).

The narrative that developed was based on substituting "credibility" (Johnson, 1997) and "dependability" (Lincoln and Guba, 1985) for "reliability" (Strauss and Corbin, 1990).

This research focus utilises authentic observations reflecting the experience level of toxic leaders and the impact of their practices (Lambsdorff, 1998) designed to help build an analysis in the "interests of the public good" and engaging in a "...good-faith effort to report wrongdoing..." (Sinzdak, 2008).The author relies on the World Bank and Transparency International rules for disclosure under which such research has been conducted (The World Bank, 2010; G20, 2011; OECD, 2014; BSI, PAS 1998:2008; PCAW, 2018). This is as a consequence of the publication of a World Bank NRA directly involving the JV Lead Management (The World Bank, 2017) during the research investigations. 


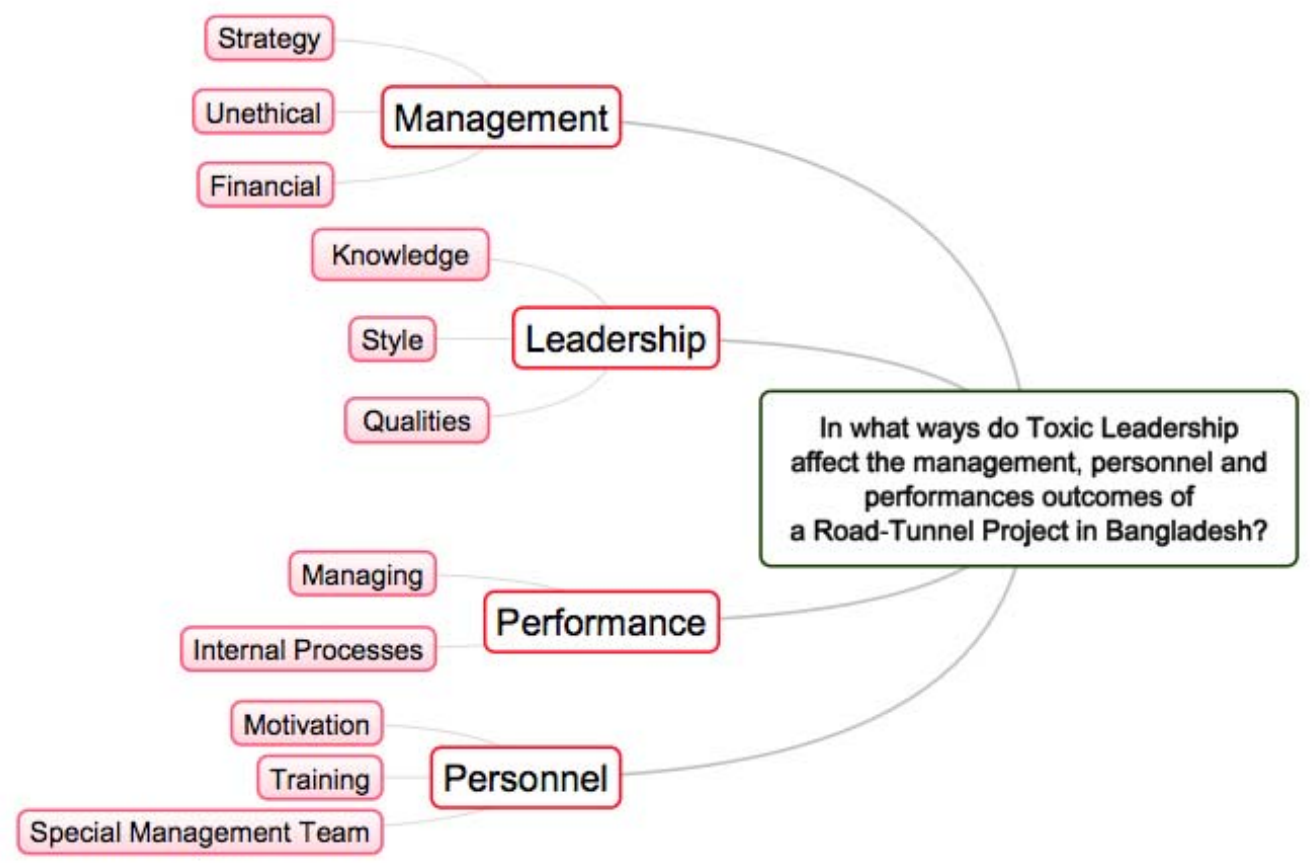

Figure 1. Research Outcomes

Illustration of Research Outcomes

The research outcomes for this analysis is shown in Figure 1 above. The outcomes are illustrated below in Table 1 and consists of four (4) main themes - Management, Performance, Personnel, and Leadership, and eleven (11) sub-themes with265 discussion targets. The discussion focuses on the sub-theme elements within each major key theme. The respondent's voice is revealed through a streamlined and articulated approach verbatim, where the reporting format is persuaded by Gonzalez (2008) and Daniels et al. (2007). 
Table 1. Research question, themes and discussion targets

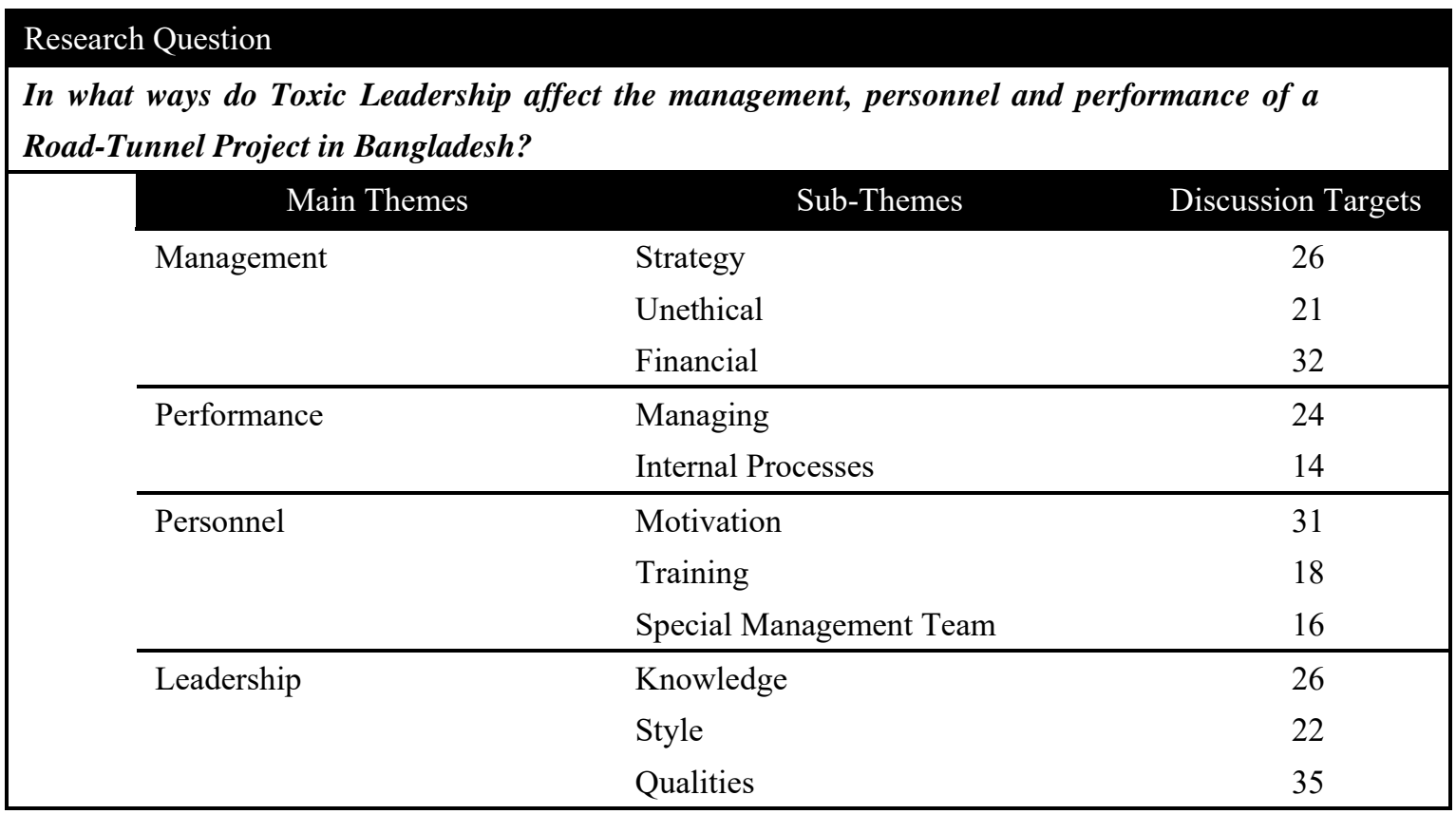

Table 1 above indicates the minimum responses for each identified sub-theme.

Table 2. Major themes and respondent citations

\begin{tabular}{|l|l|}
\hline Major Themes & \multicolumn{1}{c|}{ Cited Respondent Number } \\
\hline Management & $1,3,5,6,8,9,10,11,12$ \\
\hline Performance & $2,4,5,7,9,13$ \\
\hline Personnel & $2,4,5,6,8,9,10,12,14$ \\
\hline Leadership & $1,3,4,5,7,8,10,11,13,14$ \\
\hline
\end{tabular}

Table 2 above indicates the major themes and respondent citations.

\section{Results}

The results are presented below, using extracted evidence through specified abstractions as based on Gonzalez, (2008). Consequently, by considering the research question - In what ways do Toxic Leadership affect the management, personnel and performance of a Road-Tunnel Project in Bangladesh?- the results are stated here as four (4) main-themes, and eleven (11) sub-themes as indicated in Table 1 and 2 above, where each sub-theme theme is located and examined within each respective associated main-theme.

\section{Main Theme - Management}

In terms of Strategy, this is typified by one respondent (9) who suggested that, ...Of course, the main strategy for them [JV Lead Management]is to make sure they aren't caught for doing anything wrong. Their second strategy is to attack people to make them weak, so they can do what they want. There are no leaders here... Another respondent (6) denoted that,...They have been doing this for many projects and a long time. Another respondent (5) stated that,...They 
must train themselves to ignore the risks or they are so powerful that he don't need to lead us, just tell us what to do. And if we don't, to make it difficult for us...

In terms of Unethical, this is demonstrated by one respondent (3) who denoted that, ...Oh, they[JV Lead Management]are really sneaky. They don't do things properly or ignore professional ways...Another respondent (1) signified that,... They humiliate people, they attack them sometimes openly and calls them names, and they are also racist. Not what is expected of a foreigner company...Another respondent (12) stated that,...There are other foreigners, but they go very quickly. They must see what they do. I don't understand it. But it can't be right for a foreigner to do this here...

In terms of Financial, this is illustrated by one respondent (10) who intimated that, ...They[JV Lead Management]always have lots of money on them, and I mean a lot. They use the project money for all their personal spending, drinks an' all. They are a dangerous leader for us all...Another respondent (11) expressed that, ...For the people who follow them, they buy lots for them. They do not follow proper behaviour, and they close the door, when they want to talk about, y' know “things that can't be spoken about”... Another respondent (8) articulated that,...They goes from here, with a wad of money. We see administration go to the bank to get it. And then it's gone. I thought this is not right...

\section{Main Theme - $\underline{\text { Performance }}$}

In terms of Managing this is epitomized by one respondent (2) who denoted that, ...It like a game to them [JV Lead Management]. They get rid of someone for no reason or prevents them from doing any work by making them sit in a corner for months and months. They laugh and smile. It just isn't right... Another respondent (7) stated that, ...I think they should be fired, for what they do. They're amateurs, playing silly games. But those in top management are not so good either. They support him because he provides them with dishonest money from the project. We see it all the time... Another respondent (13) voiced that,...They don't manage really. They just dictate, power driven that's what they are. The project would be better without them. Some of the foreigner are hiding here without any talent...

In terms of Internal Processes this is typified by one respondent (4) who indicated that, ...They [JV Lead Management] maliciously hold back information that we need. They do it deliberately. It has caused serious problems because it involves people doing the same thing over again. They do it all the time... Another respondent (9) expressed that,...Management [JV Lead Management]sign things in place of everyone. Reports are "lost" all the time. They also sign to state that, for example, one manager is the sole writer, checker and authoriser of project reports. This way they make sure no one else represents the project to the employer. They are unbelievable... Another respondent (5) articulated that, ...They don't follow any process or procedure. They just invent what they think will be accepted. They do this on all projects they've been on. They're fooling no-one...

\section{Main Theme $-\underline{\text { Personnel }}$}

In terms of Motivation this is exemplified by one respondent (8) who indicated that,...There is no due process in action. They [JV Lead Management] fail to use any procedure or process. 
And then expects us to accept what they do. They really aren't professional. No, not at all... Another respondent (4) conveyed that,...The managers [JV Lead Management] ensures that no one is motivated to do anything against him. It is not acceptable, ruling like a dictator...Another respondent (12) expressed that, ...No one trusts them. But what can we do?...

In terms of Training this is characterised by one respondent (5) who denoted that,... There has been no teambuilding on this project. Why would there be? You just do what the management [JV Lead Management]says you do and that's it... Another respondent (10) stated that, ...I would estimate that we could all do with some training - including them[JV Lead Management]. But I don't suppose we will get it... Another respondent (14) expressed that, ... The managers say that it is the cost that prevents training. But I think they don't want it, who are frightened that we might learn something that will show how ineffective they are as a leader. Some who are trained overseas already see this...

In terms of Special Management Team this is epitomized by one respondent (9) who signified that, ...I was wondering why the management[JV Lead Management]made changes to the personnel who were named and supposed to be on the project. They got rid of people and replaced them with their "Special Team". None of these do much for the project, except to take money... Another respondent (6) affirmed that, ... Oh yes. Very few who were originally named were on the project and I suppose they never will. They have taken the money that they should have received and allocated it, and given it to people who we don't see... Another respondent (2) suggested that, ...That's an interesting issue. The client would not approve anyone for a very long time and that made it difficult for the work load. However, after the last variation order, all of a sudden, we now have approvals for people we didn't even know or were financed for other projects. But they are mostly on other projects not this one...

Main Theme - Leadership

In terms of Knowledge this is exemplified by one respondent (4) who denoted that, ...No, I don't think they[JV Lead Management]have any professional training. None. They're really arrogant and ignorant for people who don't understand project management... Another respondent (11) expressed that,... They say they have many years' experience in this role. But it doesn't show. We're better off without them... Another respondent (13) expressed that,...They are not that qualified for foreigners on a flag-ship project. There are better available I am sure... Another respondent (7) expressed that, ...I am not proud that they do this. Surely, they [JV Lead Management] could have found someone better. They aren't qualified really. No leaders just hangers on...

In terms of $\underline{\text { Style }}$ this is characterised by one respondent (8) who signified that, ...They [JV Lead Management]just demand aggressively something, and they get very angry if you don't agree to do it straightaway... Another respondent (3) expressed that, ...You can see it in their eyes, they don't want you to discuss things, you just have to do it... Another respondent (11) articulated that, ... They will always do what the client wants. And if you happen to disagree professionally, they will make it obvious in client meetings that you were the problem - even if you were right according to the contract or the law... Another respondent (5) indicated 
that, ...I am not impressed with them managing people. It just isn't the right that they can do this in their job. But everyone knows they will make you manipulate things so that he get their way...

In terms of Qualities this is typified by one respondent (1) who stated that, ...They [JV Lead Management] lack proper professional qualities such as integrity, and they're hypocritical and very untrustworthy as they say one thing between you or in a meeting and then decide on doing something else between them... Another respondent (10) expressed that, ...What I don't like is that they have no vision, at least they can't show what they think and turn it into something we can understand... Another respondent (7) articulated that,... We see it all the time, they lack communication skills, and their meeting style is very aggressive, so we don't want to say anything for fear of their anger and temper... Another respondent (14) stated that, ...I don't want to follow them. No one here does...

\section{Research Consideration and Implications}

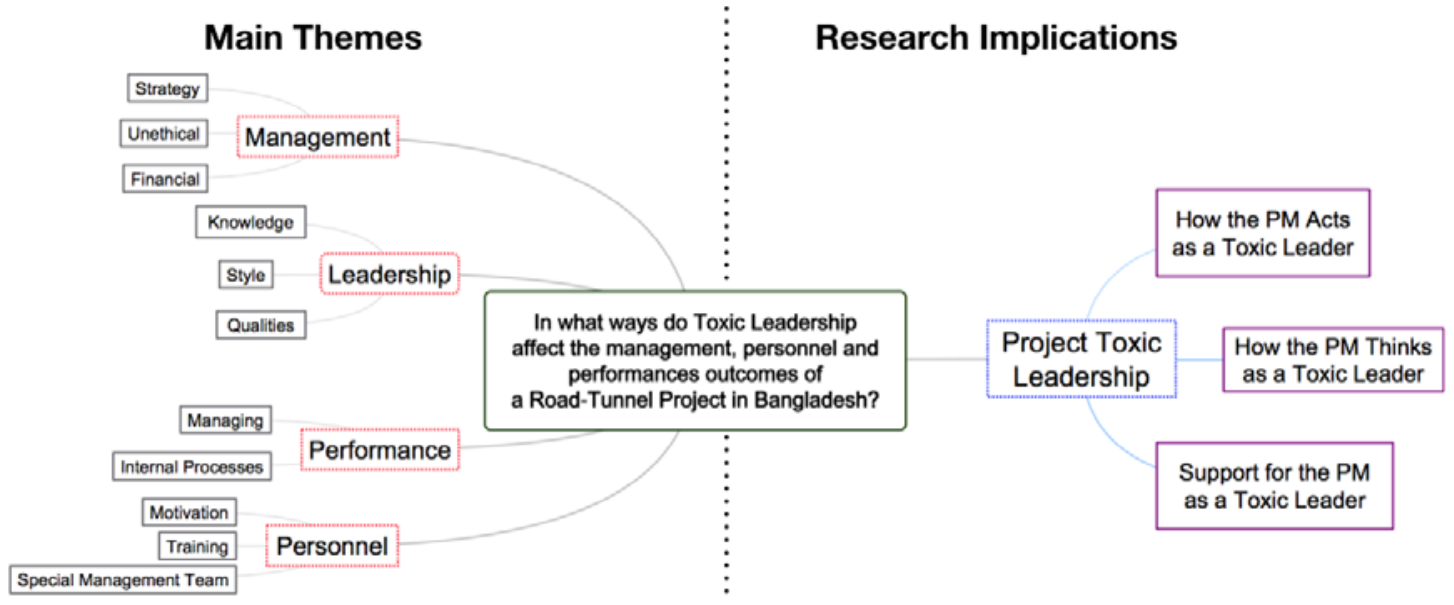

Figure 2. Research Consideration

The outline discussion of the research implications for this study is shown in Figure 2 above, and are considered further below:

The JV Lead management appears to have failed to adopt one of the 11 main principles of project governance (APM, 2004), which is to properly prioritise projects goals leading to ineffective management, project disarray and inefficiencies such as delays to the project schedule (Chan and Kumaraswamy, 1997) creating additional project cost. However, most researchers would indicate that from such data, a collaborative effort is required (Mehra, 2006) utilising inspirational motivation (Bass, 1990) and therefore, the JV Lead management appears to reflect organisational autocrats whose focus is to manipulate staff (Richards and Freeman, 2002) and processes through unethical practices, without proper authorisation, appropriate oversight or project outcomes that are contractually underpinned. The JV Lead management appears to lack the very skills necessary to manage the project both in technical terms and in relation to people skills (Thomas and Mengel, 2008) - raising the issue of employing unqualified managers with no project management qualifications - but this may not be seen by 
the JV Lead management as important as the overly ulterior focus is on personal Client engineer satisfaction. Further, the JV Lead management's toxic leadership behaviour has reportedly resulted in many instances of individuals being forced to withdraw from the group which has a destructive effect on group dynamics (Bass, 1990; Arrow and McGrath, 1995) causing further negative effects on individual trust and lowering JV staff leader confidence (PMBOK® Guide, 2013; Howell and Avolio, 1992).

Accordingly, this project may be one of many controlled by the JV Lead management, where toxic leadership behaviour is employed and conducted in a negative vacuum approximating as "resisters" to enhancing unabridged project performance in order to hide collusion (Locatelli, et al., 2017). There is therefore a substantial, on-going and unmitigated failure by the JV Lead management (Goldman, 2009) to pay due regard to the underlying ethical considerations (Green, 2014) and potential "unintended" performance consequences of negative project leadership impacts on operations (Colligan and Higgins, 2006). These include reductions in overall supervisory staff, leading to unsatisfactory Works/site coverage, unclear deadlines associated with milestone accomplishment through contract manipulation, and reduced funds available for project completion through reductions in available project funds to cover contractual obligations.

\section{How the JV Lead Management Acts as a Toxic Leader}

The current style offered by the JV Lead management does not appear to follow any of the modern depictions of positive leadership theory as it is perceived to have no representation in authentic leadership (Luthans and Avolio, 2003), lacking cognitive leadership (Lord and Hall, 2005), showing no ethical leadership (Brown, Trevino and Harrison, 2005) or willing capacity to engage with complexity leadership (Uhl-Bien, Marion and McKelvey, 2007). Further, the JV Lead management does not appear to perform because of failure to harness appropriate leadership dynamics such as leadership exchange (Cogliser and Schriesheim, 2000) as required from a modern complex project (James, 2016). Further, the portrayed leadership style demonstrates a consistent threat to organisational stability (Vugt et al., 2003) through a culture of arrogancy, secrecy and restrictiveness (Avolio, Walumbwa and Weber, 2009; Kusy and Holloway, 2009).

However, the operationalised JV Lead management's autocratic leadership style (Bass and Bass, 2008) is clearly represented in the past (Lichtenstein et al., 2007), reflecting the JV Lead management's incapacity to meet contemporary project management requirements (APM, 2012) through a lack of professional training or team-building capability (Ivancevich, Konopaske and Matteson, 2007).Further, the lack of team definition coupled with the perceived low credibility and maturity of the JV Lead management(Simons, 1999), which has a negative effect on group motivation and project personnel responses to operational project issues. Additionally, the JV Lead management as a project leader, appears to be considered a bully (Wyatt and Hare, 1997; Rayner and Cooper, 1997) materially archaic, hostile (Tepper, 2000)and provides little or no opportunity for shared decision-making (Yang, Wang and Jin, 2014). These are considered to resonate against contemporary needs for positive approaches to managing and leading a complex project, whose definitions and technical orientation are 
closely classed as a major infrastructure innovation in Bangladesh (Bossink, 2004; Galbraith, 1982). Thus, the JV Lead management's lack of engagement in an appropriate leadership role affects the project by reducing task capability (Grant, 1996) and consequent trust (Russell and Stone, 2002; Piccolo and Colquitt, 2006) creating a negative work environment that reinforces mediocre project performances resulting from ineffective complexity management (Uhl-Bien, Marion and McKelvey, 2007). It also leaves the JV Lead management open to inferior outcomes and legal issues resulting from inadequate and improper application of organisational compliance (Lippel, 2010; Tavanti, 2011) - something which has already been independently recognised (The Work Bank, 2017).

\section{$\underline{\text { How the JV Lead Management Thinks as a Toxic Leader }}$}

The JV Lead management as awhole-project lead entity appears to think that it has the right and duty to operate in the way that they do with clear indications of misplaced confidence, poor judgement and the absence of quality practices (Furnham, 2010) - presupposing a selective interpretation of reality (Mumford et al.,2007)by acting as a corporate psychopath (Boddy, Ladyshewsky and Galvin, 2010).The JV Lead management entity also appears to think that it can violate organisational legitimacy and rules (Yen, Tian, and Sankoh, 2013) through overt subterfuge and sabotage whilst ignoring staff requirements (Flynn, 1999), their well-being(Einarsen, Aasland and Skogstad, 2007; Reed, 2004) and also legal and ethical obligations (corporate restrictions through international group oversight processes and contractual and other compliance requirements).

The JV Lead management's demonstrated narcissistic and hostile attitude and demeanour (Rosenthal and Pittinsky, 2006) may provide the reason for it's exploitative managerial practices and non-technical capability as the reason for the lack of technical engagement (Lane, 2004). However, it does not provide a basis for the support given by the out-of-country JV Lead corporate management (worryingly located in Singapore), as the JV Lead management and corporate management do not follow expected internally transparent prescribed rules and operational procedures (Lipman-Blumen, 2006). Consequently, the inherent leadership practices of the JV Lead managementappear to come from "being allowed" to act unprofessionally (Mehta and Maheshwari, 2014) - simultaneously across multiple projects -suggesting an out of control operational entity (Carver and Scheier, 1982), where the leadership style is based on impulse, aggression (Bowling and Beehr, 2006) and the need for control resulting from collusion and fraud constraints with "business as usual" (Anand, Ashforth and Joshi, 2004).

\section{The Support for the JV Lead Management Toxic Leadership}

The JV Lead management appear to endorse and utilise a systemic culture of unsympathetic leadership engagement (Attridge, 2009)and abusive supervision (Tepper, 2007) that shows little respect for ordinary staff (Hornstein, 1996) - as these staff appeared to be manipulated and ignored. However, the JV Lead management appears to command at will, support to ensure all staff tow the line - even when this was blatantly against ethical standards -within a culture where individuals who conformed to such standards were perceived to be irrationally targeted, abused and discredited (Ashforth, 1994). 


\section{MlMacrothink}

Journal of Management Research

ISSN 1941-899X

2018, Vol. 10, No. 2

The stated notion of "petty tyranny" associated with the JV Lead management's overall leadership behaviour (Kant, et al., 2013; Akhtar and Shaukat, 2016) does little to provide the confidence that their collective behaviour will be halted, or that the JV Lead management recognises that there are distinct and peculiar problems associated with their leadership style and behaviour.

Further, as the JV Lead management appears to favour only individuals within its operational clique, akin to a derailed leader (Furnham, 2010), which results in a lower "moral intensity" (Jones, 1991), heightened need for power (Kellerman, 2004), and incongruent values and beliefs to those outside their circle (Padilla, Hogan and Kaiser, 2007). There would also appear to be substantive negative issues that have developed that impact on the project performance through a complicit (Goldman, 2009a) and secretive JV Lead management agenda (Macpherson, 2015; Kets de Vries and Miller, 1984) leaving important contractual obligations unfulfilled. This has both impacts on the JV Lead management's reputation (Lipman-Bluman, 2006) and also incurs greater cost and reduced project value within a predisposed and unhealthy corporate culture (Kusy and Holloway, 2009).

The CEO of the JV lead management's International entity is reported not to have responded to any (multiple) issues raised through requests for help by JV Lead management staff in order to solve such problems with toxic leadership and as such are considered culpable through the lack of appropriate governance and mismanagement. This also leads to raised issues of lack of engagement by International JV Lead management implementation processes and lack of use of employer Business Integrity Compliance protocols surrounding stated rules, boundaries and limitations (reference not provided due to privacy issues).

\section{Reducing the JV Lead Management's toxic leadership engagement and impact}

The JV Lead management appears to lack a professional understanding and engagement of the project's technical, procedural, process and interpersonal skills requirements for the project (Barnes, 1988; Oppong, Chan and Dansoh, 2017; PMBOK® Guide, 2013) and subsequently need retraining (Reichard and Avolio, 2005; Roberts et al., 2005). Further, the management overseeing the project needs to review and assess their support of a situation that is determined as illegal and unethical where there does not appear to be any constructive leader engaged in the management of the project.

Some indications for reducing toxic leadership, enhancing leadership capability and reducing negative leadership experiences (Greyvenstein and Cilliers, 2012) could include:

1. Engage in more appropriate learning and training (Sense, 2003)

2. Develop rehabilitation and retraining programmes for project management in terms of technical, people, process and social skills (Goldman, 2011)

3. Identify JV Lead Management bullying and harassment behaviour issues (Richards and Freeman, 2002) and provide legitimate avenues (formal and informal) for staff making claims regarding unwanted leader behaviours (Aasland, et al., 2010) 
4. Introduce supervised HR programmes to underpin corporate development in governance and procedure - in-country and overseas (Bjugstad, et al., 2006; Fevre, et al., 2012; Goldman, 2009a)

\section{Conclusions}

It would appear that the focus of toxic leadership associated with the JV Lead management isn't just considered a personal deviant behaviour but appears to be representative of a much larger systemic feature of illicit management practices in the JV Leadentity (O'Connor and Quinn, 2010). Further, since there is a consistent lack of unconvincing oversight by the JV Lead management and/or its International managing entity, there is no residual managerial intervention on reported incidents as theJV Lead management acts as an agent of the client engineer (Cerić, 2015). Consequently, there would appear to be a governance failure (Finkelstein, 2005) to comprehend the wider implications of toxic leadership behaviour on the project performance as a whole (Hoel and Salin, 2003) and on the individual engineers concerned (Too and Weaver, 2014). Further, staff are being left without help and are comprehensively ignored by in-country management, which raises considerable issues of organisational support where such individuals may experience potential harm because of the underlying ethical considerations and potential unintended consequences of toxic leadership.

The reduction of toxic leadership is necessary in the organisation (Jones, 1999) in order to deliver a project that has the quality, within budget and schedules - according to professional, contractual and technical requirements. Inevitably, this could mean increasing training demands (Pelletier, 2010) and providing more effective governance as well as a more effective leader for the position of the JV Lead management for this project.

The JV Lead management's vitriolic leadership activities, in partnership with the international management, through pervasive lack of external governance from the Lead JV located in Singapore, appears to have conducted similar patterns of misconduct in other unrelated projects - but also managed by the same managerial group. The impact of the JV Lead management's toxic leadership and negative behaviour is therefore widespread, profound and undesirable in a modern infrastructure project through indifference to articulated professional conduct requirements and the people involved in transforming and delivering client requirements through an appropriate legal and technical undertaking (Warren, 2003). Thus, toxic leadership and masked corruption are compounded by decisions of the World Bank (The Work Bank, 2017), which appears to have undermined the public character and professional legitimacy of the International JV Lead management.

\section{References}

Aasland, M. S., Skogstad, A., Notelaers, G., Nielsen, M. B., \& Einarsen, S. (2010). The prevalence of destructive leadership behaviour.British Journal of Management, 21(2), 438-452. https://doi.org/10.1111/j.1467-8551.2009.00672.x

Akhtar, S., \& Shaukat, K. (2016).Impact of Petty Tyranny on Alienation from Work: Role of Self-Esteem and Power-Distance. Global Journal of Flexible Systems Management, 17(3), 275-285. 
Anand, V., Ashforth, B., \& Joshi, M. (2004).Business as usual: The acceptance and perpetuation of corruption in organizations. Academy of Management Perspectives, 18(2), 39-53. https://doi.org/10.5465/AME.2004.13837437

APM. (2012). APM Body of Knowledge. $6^{\text {th }}$ Edn. Association for Project Management, Buckinghamshire, UK.

APM. (2004). Directing change: A guide to governance of project management.Association for Project Management, High Wycombe, UK.

Arrow, H., \& McGrath, J. (1995). Membership dynamics in groups at work.A theoretical framework. In: Staw, B.,\& Cummings, L. (Eds.), Research in organizational behavior (Vol. 17, 373-411). JAI, Greenwich, CT, USA.

Ashforth, B. (1994). Petty tyranny in organizations.Human Relations, 47(7), 755-778. https://doi.org/10.1177/001872679404700701

Attridge, M. (2009). Measuring and Managing Employee Work Engagement: A Review of the Research and Business Literature. Journal of Workplace Behavioral Health, 24(4), 383-398. https://doi.org/10.1080/15555240903188398

Avolio, B., Walumbwa, F., \& Weber, T. (2009). Leadership: Current Theories, Research, and Future Directions. Annual Review of Psychology, 60, 421-449. https://doi.org/10.1146/annurev.psych.60.110707.163621

Baccarini, D. (1999). The logical framework method for defining project success. Project Management Journal, 30(4), 25-32.

Bailey, K. (2008). Methods of Social Research. New York, The Free Press, USA.

Balshem, M. (1991). Cancer, Control and Causality: Talking about Cancer in a Working-Class Community. American Ethnologist, 18(1), 152- 172. 10.1525/ae.1991.18.1.02a00070

Barnes, M. (1988). Construction project management. International Journal of Project Management, 6(2), 69-79. https://doi.org/10.1016/0263-7863(88)90028-2

Bass, B. (1990). Bass and Stogdill's handbook of leadership: Theory, research and management applications. Free Press, New York, USA.

Bass, B., \& Bass, R. (2008). The Bass Handbook of Leadership: Theory, Research and Managerial Application. Simon \& Schuster, New York, USA.

Benn, N., Buckingham, S., Domingue, J., \& Mancini, C. (2008). Ontological Foundations for Scholarly Debate Mapping Technology. In: $2^{\text {nd }}$ International Conference on Computational Models of Argument (COMMA '08), Toulouse, France.

Bjugstad, K., Thach, E., Thompson, K.,\& Morris, A. (2006). A Fresh Look at Followership: A Model for Matching Followership and Leadership Styles. Journal of Behavioral and Applied Management, 7(3), 304-319. 
Blair, C., Hoffman, B., \& Helland, K. (2008).Narcissism in Organizations: A Multisource Appraisal Reflects Different Perspectives. Human Performance, 21(3), 254-276. https://doi.org/10.1080/08959280802137705

Boddy, C., Ladyshewsky, R.,\& Galvin, P. (2010). Leaders without ethics in global business: Corporate psychopaths. Journal of Public Affairs, 10(3), 121-138. https://doi.org/10.1002/pa.352

Bossink, B. (2004). Effectiveness of innovation leadership styles: a manager's influence on ecological innovation in construction projects. Construction Innovation, 4(4), 211-228. https://doi.org/10.1108/14714170410815105

Bowling, N., \& Beehr, T. (2006). Workplace harassment from the victim's perspective: A theoretical model and meta-analysis. Journal of Applied Psychology, 91(5), 998-1012. https://doi.org/10.1037/0021-9010.91.5.998

Branham, L. (2005). The 7 Hidden Reasons Employees Leave: How to Recognize the Subtle Signs and Act before It's Too Late. American Management Association, New York, USA.

Brown, M., Trevino, L., \& Harrison, D. (2005). Ethical leadership: a social learning perspective for construct development and testing. Organizational Behavior and Human Decision Processes, 97(2), 117-134. https://doi.org/10.1016/j.obhdp.2005.03.002

BSI, PAS 1998:2008 (2008). Whistleblowing Arrangements Code of Practice. BSI, London, UK.

Buckingham, M. \& Coffman, C. (1999). First, Break All the Rules: What the World's Greatest Managers Do Differently, Simon \& Schuster, New York, USA.

Buston, K. (1999). NUD*IST in action: its use and its usefulness in a study of chronic illness in young people. In: Bryman A., and Burgess R.G., (Eds.) Analysis and Interpretation of Qualitative Data, Sage Publications, London, UK.

Carman, J. (1990). Consumer Perceptions of Service Quality: An Assessment of the SERVQUAL Dimensions. Journal of Retailing, 66(1), 33-55.

Carver, C., \& Scheier, M. (1982). Control theory: A useful conceptual framework for personality-social, clinical, and health psychology. Psychological Bulletin, 92(1), 111-135. https://doi.org/10.1037/0033-2909.92.1.111

Cassell, C., \& Symon, G. (2004). Essential Guide to Qualitative Methods in Organizational Research. Sage Publications, London, UK.

Cavaleri, S., \& Reed, F. (2008).Leading dynamically complex projects. International Journal of Managing Projects in Business, 1(1), 71-87. https://doi.org/10.1108/17538370810846423

Cayla, J., \& Eckhardt, G. (2007). Asian Brands without Borders: Regional Opportunities and Challenges. International Marketing Review, 24(4), 444-456. https://doi.org/10.1108/02651330710761017 
Cerić, A. (2015). Trust in Construction Projects. Routledge, London, UK.

Chan, D., \& Kumaraswamy, M. (1997). A comparative study of causes of time overruns in Hong Kong construction projects. International Journal of Project Management, 15(1), pp. 55-63. https://doi.org/10.1016/S0263-7863(96)00039-7

Cogliser C., \& Schriesheim C. (2000). Exploring work unit context and leader-member exchange: a multi-level perspective. Journal of OrganisationalBehavior,21(5), 487-511. https://doi.org/10.1002/1099-1379(200008)21:5<487::AID-JOB57>3.0.CO;2-P

Colligan, T., \& Higgins, E. (2006). Workplace stress: Etiology and consequences. Journal of Workplace Behavioral Health, 21(2), 89-97. https://doi.org/10.1300/J490v21n02_07

Conger, J. (1989). The Charismatic Leader.Jossey-Bass, San Francisco, CA, USA.

Conger, J. (1990). The dark side of leadership. Organizational Dynamics, 19(2), 44-55. https://doi.org/10.1016/0090-2616(90)90070-6

Crawford, I. (2000). Profiling the competent project manager. Proceedings of PMI research conference, Project Management Institute, PA, USA.

Daniels, J., et al. (2007). The Successful Resolution of Armed Hostage/Barricade Events in Schools: A Qualitative Analysis. Psychology in the Schools, 44(6), 601-613. https://doi.org/10.1002/pits.20250

Duranti, A. (2007). Transcripts, like Shadows on a Wall. Mind, Culture, and Activity, 13(4), 301-310. https://doi.org/10.1207/s15327884mca1304_3

Einarsen, S., Aasland, M., \& Skogstad, A. (2007). Destructive leadership behaviour: a definition and conceptual model. The Leadership Quarterly, 18(3), 207-216. http://dx.doi.org/10.1016/j.leaqua.2007.03.002

Fevre, R., Lewis, D., Robinson, A., \& Jones, T. (2012). Trouble at work. Bloomsbury, London, UK.

FIDIC (1999).Silver Book 1999 - Conditions of Contract for EPC/Turn Key Projects. FIDIC, Geneva, Switzerland.

Fink, A. (2000). The Role of the Researcher in the Qualitative Research Process. A Potential Barrier to Archiving Qualitative Data. Forum: Qualitative Social Research, 1(3), article 4.

Finkelstein, S. (2005). When bad things happen to good companies: strategy failure and flawed executives. Journal of Business Strategy, 26(2), 19-28. https://doi.org/10.1108/02756660510586300

Flynn, G. (1999). Stop toxic leaders before they stop you! Workforce, August, 44-46. [Online] Available: www.workforce.com/archive/feature/22/22/12/223888/php

Furnham, A. (2010). The Elephant in the Board Room. Palgrave Macmillan, Basingstoke, UK. http://dx.doi.org/10.1057/9780230281226 
G20, (2011). Protection of Whistleblowers. G20 Anti-Corruption Action Plan, Summit in Cannes, G20 Leaders provided, in the endorsed Monitoring Report of the G20 Anticorruption Working Group.

Galbraith, J. (1982). Designing the innovating organization. Organizational Dynamics, 10(3), 5-25, Winter. http://dx.doi.org/10.1016/0090-2616(82)90033-X

Glaser, B.,\& Strauss, A. (1967). The Discovery of Grounded Theory: Strategies for Qualitative Research. Aldine, Chicago, US.

Goldman, A. (2011). Demagogue to dialogue. An alternative to toxic leadership in corporate downsizings. Organisational Dynamics, $40(3)$, 235-241.http://dx.doi.org/10.1016/j.orgdyn.2011.04.011

Goldman, A. (2009a). Destructive Leaders and Dysfunctional Organizations: A Therapeutic Approach. Cambridge University Press, New York, USA.

Goldman, A. (2009). Transforming Toxic Leaders. Stanford Business Books, Stanford University Press, CA. USA.

Gonzalez, C. (2008). Conceptions of, and approaches to, teaching online: a study of lecturers teaching postgraduate distance courses. Higher Education, 57(3), 299-314. https://doi.org/10.1007/s10734-008-9145-1

Grant, R. (1996). Prospering in Dynamically-Competitive Environments: Organizational Capability as Knowledge Integration. Organization Science, 7(4), 375-387.

Gray, J.,\& Wilcox, B. (1995). Good Schools, Bad Schools. Open University Press, UK.

Green, J. (2014). Toxic Leadership in Educational Organizations. Education Leadership Review, 15(1), 18-33.

Greyvenstein, H., \& Cilliers, F. (2012). Followership's experiences of organizational leadership: A systems psychodynamic perspective. South African Journal of Industrial Psychology, 38(2), 1-10. http://dx.doi.org/10.4102/sajip.v38i2.1001

Harms, P., Spain, S., \& Hannah, S. (2011). Leader development and the dark side of

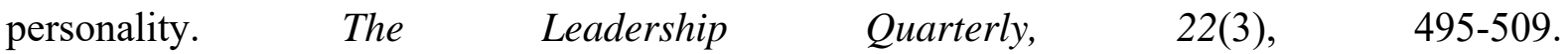
https://doi.org/10.1016/j.leaqua.2011.04.007

Harris, L., \& Brown, G. (2010). Mixing interview and questionnaire methods: Practical problems in aligning data. Practical Assessment, Research and Evaluation, 15(1), 1-19.

Harris, K., Kacmar, K., \& Zivnuska, S. (2007). An investigation of abusive supervision as a predictor of performance and the meaning of work as a moderator of the relationship. The Leadership Quarterly, 18(3), 252-263. https://doi.org/10.1016/j.leaqua.2007.03.007

Harvey, P., Stoner, J., Hochwarter, W., \& Kacmar, C. (2007). Coping with abusive supervision: the neutralizing effects of ingratiation and positive affect on negative employee outcomes. The Leadership Quarterly, 18(3), 264-280. https://doi.org/10.1016/j.leaqua.2007.03.008 
Harwood, T., \& Garry, T. (2003).An Overview of Content Analysis. The Marketing Review, 3(4), 479-498. https://doi.org/10.1362/146934703771910080

Higgs, M. (2009). The good, the bad, and the ugly: Leadership and narcissism. Journal of Change Management, 9(2), June, 165-178. https://doi.org/10.1080/14697010902879111

Hill, C, Thompson, B., \& Williams, E.(1997). A guide to conducting consensual qualitative research. The Counseling Psychologist, 25(4), 517-572. https://doi.org/10.1177/0011000097254001

Hillson, D. (2003). Assessing Organizational Project Management Capability. Journal of Facilities Management, 2(3), 298-311. https://doi.org/10.1108/14725960410808276

Hoel, H., \& Salin, D. (2003). Organisational antecedents of workplace bullying. In: Einarsen, S., Hoel, H., Zapf, D., \& Cooper, C. (Eds). Bullying and emotional abuse inthe workplace: International perspectives in research and practice. Taylor \& Francis, London, UK.

Hogan, J., Hogan, R., \& Kaiser, R. (2003). Management derailment: personality assessment and mitigation. In: Zedeck, S. (ed.). American Psychological Association Handbook of Industrial and Organizational Psychology. American Psychological Association, Washington, DC, USA.

Howell, J.,\&Avolio, B. (1992). Transformational Leadership, Transactional Leadership, Locus of Control, and Support for Innovation: Key Predictors of Consolidated-Business-Unit Performance. Journal of Applied Psychology, 78(6), 891-902. https://doi.org/10.1037/0021-9010.78.6.891

Ivancevich, J., Konopaske, R., \& Matteson, M. (2007). Organization Behaviour and Management. McGraw-Hill Irwin, New York, USA.

Jäger, C. (2008). The Principal-Agent Theory within the Context of Economic Sciences. Norderstadt, Herstellung und Verlag, Germany.

James, P. (2016). Assessing Contractor's Innovation Issues in a Large Complex Civil Engineering Project in Pakistan. International Journal of Applied Engineering Research, 11(15), 8452-8463.

James, P. (2015). Corruption in the Middle East Management Implications at a Qatar Construction Project. Journal of Management Research, 7(5), 79-95. https://doi.org/10.5296/jmr.v7i5.8379

James, P. (2014). Managerial Challenges Impacting on Contractor Led Tunnel TBM Design: A Kingdom of Saudi Arabia Metro Project. Engineering Management Research, 3(2), November, 2014.

James, P. (2005). Total Quality Management in Asia: Practices for the 21st Century. Pearson, Singapore.

James, P., \& James, T. (2011). Qualitative Research Methods for Health Services, Megellan UK Press, London, UK. 
Jones, R. (1999). Dysfunctional behavior in organizations, part A: violent and deviant behavior, part B: non-violent dysfunctional behavior in organizations. Personnel Psychology, 52(3), 771-775.http://dx.doi.org/10.1111/j.1744-6570.1999.tb00180.x

Jones, T. (1991). Ethical decision making by individuals in organizations: an issue-contingent model. Academy of Management Review, 16(2), 366-395.http://dx.doi.org/10.2307/258867

Johnson, B. (1997). Examining the validity structure of qualitative research. Education, 118(3), 282-292.

Kant, L. Skogstad, A., Torsheim, T., \& Einarsen, S. (2013). Beware the Angry Leader: Trait Anger and Trait Anxiety as Predictors of Petty Tyranny. Leadership Quarterly 24(1), 106-124. https://doi.org/10.1016/j.leaqua.2012.08.005

Kellerman, B. (2004). Bad Leadership: What It Is, How It Happens, Why It Matters. Harvard Business School Press, Boston, MA., USA.

Kets de Vries, M.F.R., \& Miller, D. (1984). The neurotic organization: Diagnosing and changing counterproductive styles of management. Jossey-Bass, San Francisco, USA.

Kim, Y. (2011). The Pilot Study in Qualitative Inquiry: Identifying Issues and Learning Lessons for Culturally Competent Research. Qualitative Social Work, 10(2), 190-206. https://doi.org/10.1177/1473325010362001

Kusy, M., \& Holloway, E. (2009). Toxic workplace: Managing toxic personalities and their systems of power. Jossey-Bass, San Francisco, USA.

Lambsdorff, G. (1998). An Empirical Investigation of Bribery in International Trade. European Journal for Development Research, 10(1), 40-59. https://doi.org/10.1080/09578819808426701

Lane, H. (2004). The Blackwell Handbook of Global Management: A Guide to Managing Complexity. Wiley-Blackwell, New York, USA.

Lichtenstein, B., Uhl-Bien, M., Marion, R., Seers, A., Orton, J., \& Schreiber, C. (2007). Complexity leadership theory: an interactive perspective on leading in complex adaptive systems. In: Hazy, J., Goldstein, J.,\& Lichtenstein, B. (Eds). Complex Systems Leadership Theory: New Perspectives from Complexity Science on Social and Organizational Effectiveness, 129-141, V1.ISCE Publications, Mansfield, MA, USA.

Lim, C., \& Mohamed, M. (1999). Criteria of project success: an exploratory re-examination. International Journal of Project Management, 17(4), 243-248. https://doi.org/10.1016/S0263-7863(98)00040-4

Lincoln, Y., \& Guba, E. (1985). Naturalistic Inquiry. Sage Publications, Beverly Hills, CA., USA.

Lipman-Blumen, J. (2006). The Allure of Toxic Leaders. Oxford University Press, Oxford, UK. 
Lippel, K. (2010). The law of workplace bullying: An international overview. Comparative Labor Law \& Policy Journal, 32(1), 1-13. https://ssrn.com/abstract=1908467

Locatelli, G., Mariani, G., Sainati, T., \& Greco, M. (2017).Corruption in public projects and megaprojects: There is an elephant in the room! International Journal of Project Management, 35(3), April, 252-268. https://doi.org/10.1016/j.ijproman.2016.09.010

Lord, R., \& Hall, R. (2005). Identity, deep structure and the development of leadership skill. The Leadership Quarterly, 16(4), 591-615. https://doi.org/10.1016/j.leaqua.2005.06.003

Luthans, F., \& Avolio. B. (2003). Authentic leadership: a positive developmental approach. In: Cameron, K., Dutton, J., \& Quinn, R. (Eds). Positive Organizational Scholarship: Foundations of a New Discipline, 241-261. Berrett-Koehler, San Francisco, CA., USA.

Maccoby, M. (1999). Narcissistic Leaders, the incredible pros, the inevitable cons. Harvard Business Review, 82(1), 1-11.

Maxwell, J. (2013). Qualitative Research Design: An Interactive Approach. Sage Publications, London, UK.

Macpherson, R. (2015). Conscious Leadership: Beyond Perception and Belief. Balboa Press, Bloomington, IN, USA.

Mehra, A., Smith, B., Dixon, A., \& Robertson, B. (2006). Distributed Leadership in Teams: The Network of Leadership Perceptions and Team Performance. The Leadership Quarterly, 17(3), 232-245. https://doi.org/10.1016/j.leaqua.2006.02.003

Mehta, S., \& Maheshwari, G. (2014). Toxic Leadership: Tracing the Destructive Trail. International Journal of Management, 5(10), 18-24.

Meurer, W. et al. (2007). Qualitative Data Collection and Analysis Methods: The INSTINCT Trial. Academic Emergency Medicine, 14, 1064-1071. https://doi.org/10.1197/j.aem.2007.05.005

Müller, R., \& Turner, R. (2007). Matching the project manager's leadership style to project type. International Journal of Project Management, 25(1), 21-32. https://doi.org/10.1016/j.ijproman.2006.04.003

Mumford, M., Espejo, J., Hunter, S., Bedell-Avers, K., Eubanks, D., \& Connelly, S. (2007). The sources of leader violence. The Leadership Quarterly, 18(3), 217-235. http://dx.doi.org/10.1016/j.leaqua.2007.03.005

Niehus, P. (2011). The Toxic Manager. Toowoomba, Queensland, Aus.

O’Connor, P., \& Quinn, L. (2004). Organizational capacity for leadership. In: van Velsor, E., McCauley, C.,\& Ruderman, M. (Eds). The Center for Creative Leadership Handbook of Leadership Development. Bass, San Francisco, CA., USA. 
OECD. (2014). ADB/OECD Anti-Corruption Initiative for Asia and the Pacific Curbing Corruption in Public Procurement in Asia and the Pacific. OECD/ADB, OECD Publishing, Philippines.

Onwuegbuzie, A., \& Leech, N. (2007). Sampling Designs in Qualitative Research: Making the Sampling Process More Public. The Qualitative Report, 12(2), 238-254.

Oppong, G., Chan, A., \& Dansoh, A. (2017). A review of stakeholder management performance attributes in construction projects. International Journal of Project Management, 35(6), 1037-1051. https://doi.org/10.1016/j.ijproman.2017.04.015

Padilla, A., Hogan, R., \& Kaiser, R. (2007). The toxic triangle: Destructive leaders, susceptible followers, and conducive environments. The Leadership Quarterly, 18(3), 176-194. https://doi.org/10.1016/j.leaqua.2007.03.001

PCAW.

Guidance.[Online]

Available:http://www.pcaw.co.uk/individual-advice/guidance

Pelletier, K. (2010). Leader toxicity: An empirical investigation of toxic behavior and rhetoric. Leadership, 6(4), 373-389. https://doi.org/10.1177/1742715010379308

Pelletier, K., \& Bligh, M. (2008). The Aftermath of Organizational Corruption: Employee Attributions and Emotional Reactions. Journal of Business Ethics 80, 823-844. https://doi.org/10.1007/s10551-007-9471-8

Piccolo, R., \& Colquitt, J. (2006). Transformational leadership and job behaviors: the mediating role of core job characteristics. Academy of Management Journal, 49(2), 327-340. https://doi.org/10.5465/AMJ.2006.20786079

PMBOK® Guide. (2013).PMBOK Guide. PMI, Philadelphia, PA., USA.

Powl, A., \& Skitmore, M. (2005). Factors hindering the performance of construction project managers. Construction Innovation, 5(1), 41-51. https://doi.org/10.1108/14714170510815168

Punch, K. (2014). Introduction to Social Research: Quantitative and Qualitative Approaches. Sage Publications, London, UK.

Rayner, C., \& Cooper, C. (1997). Workplace bullying: Myth or reality - Can we afford to ignore it? Leadership and Organization Development Journal, 18(4), 211-214. https://doi.org/10.1108/01437739710182313

Reed, G. (2004). Toxic leadership. Military Review, 84, (July-August) 67-71.

Reichard R., \& Avolio, B. (2005). Where are we? The status of leadership intervention research: a meta-analytic summary. In: Gardner, W., Avolio, B.,\&Walumbwa, F. (Eds). Authentic Leadership and Practice: Origins, Effects, and Development, 203-226. Elsevier Science, Oxford, UK.

Remington, K., \& Pollack, J. (2007). Tools for complex projects. Gower Publishing Limited, England, UK. 
Richards, H., \& Freeman, S. (2002). Bullying in the workplace: An occupational hazard. Harpers Collins, MP Publishing, Isle of Man, UK.

Ritchie, J., \& Lewis, J. (2003). Qualitative Research Practice: A Guide for Social Science Students and Researchers. Sage Publications, London, UK.

Roberts, L., Dutton, J., Spreitzer, C., Heaphy, E., \& Quinn, R. (2005). Composing the reflected best-self-portrait: building pathways for becoming extraordinary in work organizations. $\begin{array}{lllll}\text { Academy of } & \text { Management } & \text { Review, } & 30(4), & \end{array}$ https://doi.org/10.5465/AMR.2005.18378874

Rosenthal, S., \& Pittinsky, T. (2006). Narcissistic leadership. The Leadership Quarterly, 17(6), 617-633. https://doi.org/10.1016/j.leaqua.2006.10.005

Rumsey, M. (2013). The Oxford Handbook of Leadership (Eds). Oxford University Press, Oxford, UK.

Russell, R., \& Stone, A. (2002). A review of servant leadership attributes: developing a practical model. Leadership Organisational Development Journal,23(3), 145-157. https://doi.org/10.1108/01437730210424

Ryan, G., \& Bernard, H. (2003). Techniques to Identify Themes. Field Methods, 15(1), 85109. https://doi.org/10.1177/1525822X02239569

Sankowski, D. (1995). The Charismatic Leader as narcissist: Understanding the Abuse of Power. Organizational Dynamics, 57-71. https://doi.org/10.1016/0090-2616(95)90017-9

Sense, A. (2003). A model of the politics of project leader learning. International Journal of Project Management, 21(2), 107-114. https://doi.org/10.1016/S0263-7863(02)00018-2

Shaw, J., Erickson, A., \& Harvey, M. (2011). A method for measuring destructive leadership and identifying types of destructive leaders in organizations. The Leadership Quarterly, 22(4), 575-590. https://doi.org/10.1016/j.leaqua.2011.05.001

Simons, T. (1999). Behavioral integrity as a critical ingredient for transformational leadership. Journal of Organizational Change Management, 12(2), 89-104. https://doi.org/10.1108/09534819910263640

Sinzdak, G. (2008). An Analysis of Current Whistleblower Laws: Defending a More Flexible Approach to Reporting Requirements. Cal. L. Rev., 96(6), 1633-1668. http://scholarship.law.berkeley.edu/californialawreview/vol96/iss6/5

Spanos, A. (1990). Towards a Unifying Methodological Framework. In: Modelling Economic Series: Readings in Econometric Methodology. In: William, C., \& Granger, J. Readings in Econometric Methodology, Clarendon Press, Oxford, UK.

Stenbacka, C. (2001). Qualitative research requires quality concepts of its own. Management Decision, 39(7), 551-556. https://doi.org/10.1108/EUM0000000005801 
Strauss, A., \& Corbin, J. (1990). Basics of Qualitative Research: Grounded Theory, Procedures and Techniques. Sage Publications, Newbury Park, Chicago, USA.

Tan, A. (2004). Why Projects fail? 1001 Reasons. Venton Publishing (M) Sdn. Bhd.

Tavanti, M. (2011). Managing Toxic Leaders: Dysfunctional Patterns in Organizational Leadership and How to Deal with Them. Human Resource Management, 6(83), 127-136. HRM(ZZL)_6-2011eng_Tavanti-M_127-136

Tepper, B. (2007). Abusive Supervision in Work Organizations: Review, Synthesis, and Research Agenda. Journal of Management, 33(3), 261-289. https://doi.org/10.1177/0149206307300812

Tepper, B. (2000). Consequences of abusive supervision. Academy of Management Journal, 43(2), 178-190. https://doi.org/10.2307/1556375

Thomas, J., \& Mengel, T. (2008). Preparing project managers to deal with complexity advanced project management education. International Journal of Project Management, 26(3), 304-310.

https://doi.org/10.1016/j.ijproman.2008.01.001

Too, E., \& Weaver, P. (2014). The management of project management: A conceptual framework for project governance. International Journal of Project Management, 32(8), 1382-1394. https://doi.org/10.1016/j.ijproman.2013.07.006

Toor, S., \& Ofori, G. (2009). Ineffective leadership: Investigating the negative attributes of leaders and organizational neutralizers. Engineering, Construction and Architectural Management, 16(3), 254-272. https://doi.org/10.1108/09699980910951663

Toor, S., \& Ofori, G. (2008). Leadership vs. management: how they are different, and why! Journal of Leadership and Management in Engineering, 8(2), 61-71.

Toor, S., \& Ogunlana, S. (2008).Leadership skills and competencies for cross-cultural construction projects. International Journal of Human Resources Development and Management, 8(3), 192-215. https://doi.org/10.1504/IJHRDM.2008.018787

Turner, R., \& Müller, R. (2005). The Project Manager's Role as a Success Factor on Projects: A Literature Review. Project Management Journal, 36(2), 49-61.

Vugt, M., Jepson, S., Hart, C., \& Cremer, D. (2003). Autocratic leadership in social dilemmas: A threat to group stability. Journal of Experimental Social Psychology, 40(1), 1-13. https://doi.org/10.1016/S0022-1031(03)00061-1

Wyatt, J., \& Hare, C. (1997). Work Abuse: How to recognise it and survive it. Schenkman Books, Rochester VT, USA.

Yang, R., Wang, Y., \& Jin, X. (2014).Stakeholders' Attributes, Behaviors, and Decision-Making Strategies in Construction Projects: Importance and Correlations in Practice. Project Management Journal, 45(3), 74-90. https://doi.org/10.1002/pmj.21412 
Yen, T., Tian, Y., \& Sankoh, F. (2013). The Impact of Prevalent Destructive Leadership Behaviour on Subordinate Employees in a Firm. American Journal of Industrial and Business Management, 3(7), 595-600. http://dx.doi.org/10.4236/ajibm.2013.37069

Yukl, G. (1999). An evaluation of conceptual weaknesses in transformational and charismatic leadership theories. The Leadership Quarterly, 10(2), 285-305. https://doi.org/10.1016/S1048-9843(99)00013-2

Walsh, S., White, K., \& Young, R. (2008). Over-Connected? A Qualitative Exploration of the Relationship between Australian Youth and Their Mobile Phones. Journal of Adolescence, 31(1), 77-92. https://doi.org/10.1016/j.adolescence.2007.04.004

Warren, D. (2003). Constructive and destructive deviance in organizations. Academy of Management Review, 28(4), 622-632. https://doi.org/10.5465/AMR.2003.10899440

The World Bank. (2017). World Bank Announces Settlement Relating to Misconduct in World Bank-Financed Projects in the South Asia region. $28^{\text {th }}$ September, Press Release No: 2018/030/INT.[Online]

Available:http://www.worldbank.org/en/news/press-release/2017/09/28/world-bank-announc es-settlement-relating-to-misconduct-in-world-bank-financed-projects-in-the-south-asia-regio n

The World Bank Integrity Compliance Guidelines. (2010). Summary of World Bank Group Integrity Compliance Guidelines. The World Bank, Washington DC, September, USA.

Wysocki, R.,\& Lewis, J. (2001).The World Class Project Manager: A professional development guide. Perseus Publishing, New York, USA. 